\title{
APLIKASI PREDIKSI KELULUSAN MAHASISWA TEPAT WAKTU MENGGUNAKAN METODE KNN
}

\author{
Faris Asrory, Joseph Dedy Irawan, Abdul Wahid \\ Program Studi Teknik Informatika S1, Fakultas Teknologi Industri \\ Institut Teknologi Nasional Malang, Jalan Raya Karanglo km 2 Malang, Indonesia \\ Farisbinirhas1@gmail.com
}

\begin{abstract}
ABSTRAK
Kelulusan tepat waktu merupakan salah satu syarat sebuah instansi pendidikan untuk mendapatkan akreditasi yang lebih baik dari DIKTI. STITNU Al Mahsuni dalam hal ini masih dalam kondisi kurang mampu untuk menjaga stabilitas kelulusannya. Dengan banyaknya langkah yang sudah di tempuh lembaga, peneliti menawarkan pembuatan aplikasi prediksi kelulusan menggunakan metode k-NN sebagai solusi untuk melakukan pendekatan terhadap masalah yang sedang di hadapi.

Metode k-NN merupakan metode yang secara umum bekerja dengan membaca pola berdasarkan parameter yang sudah di tentukan. Adapun parameter yang mempengaruhi tingkat kelulusan mahasiswa menurut pihak STITNU Al Mahsuni adalah jenis kelamin, memiliki pekerjaan/membiayai kuliah secara mandiri, status pernikahan, umur dan jurusan SMA.

Hasil penelitian menunjukkan bahwa prediksi menggunakan metode k-NN dengan parameter parameter di atas sebagai tolak ukur perhitungan dapat di lakukan.
\end{abstract}

Kata Kunci : $k$-NN, Prediki, Kelulusan Mahasiswa, Pendidikan Tinggi

\section{PENDAHULUAN}

1.1. Latar Belakang

Perguruan Tinggi adalah satuan pendidikan yang menyelenggarakan Pendidikan Tinggi. Berdasarkan data yang di peroleh dari (Pangkalan Data Pendidikan Tinggi (PDDikti), 2018) menyebutkan bahwa jumlah lembaga penyelenggara perguruan tinggi sampai dengan Desember 2018 tercatat 4.670 perguruan tinggi diselenggarakan di Indonesia, yang terdiri dari Akademi, Akademi Komunitas, Institut, Politeknik, Sekolah Tinggi dan Universitas.

STITNU Al Mahsuni bisa di kategorikan sebagai Perguruan Tinggi baru jika di bandingkan perguruan tinggi lain. Namun STITNU Al Mahsuni memiliki visi dan misi besar untuk menjadi Universitas besar dan di perhitungkan sebagai Perguruan Tinggi berkualitas di indonesia. Untuk mencapai tujuan tersebut, di perlukan Akreditasi yang baik dari dikti.

Untuk mendapatkan peningkatan akreditasi, lembaga yang bersangkutan harus memenuhi syaratsyarat yang ketat. salah satu syarat yang paling penting adalah tingkat kelulusan tepat waktu pada lembaga tersebut haruslah konsisten dalam artian jumlah peserta didik baru dengan peserta yang lulus tepat waktu haruslah berbanding lurus. namun pada kenyataannya masih masih ada peserta didik yang yang lulus pada semester yang lebih dari waktu yang di tentukan di STITNU Al Mahsuni. menurut sekretaris sekolah tinggi ilmu tarbiyah Nahdlatul ulama, hal ini terjadi karena informasi potensi keterlamabatan mahasiswa yang lulus tidak tepat waktu di rasa terlmabat untuk didapatkan. Indikasi keterlambatan bianya dapat di temukan ketika semester 6 atau 7. Sehingga dibutuhkan sebuah sistem yang mampu menangkap indikasi-indikasi keterlambatan kelulusan mahasiswa sejak dini.

Berdasarkan Masalah tersebut, penulis melakukan penelitian dengan judul "Aplikasi Prediksi Mahasiswa Lulus Tepat Waktu Menggunakan Metode KNN". dengan adanya aplikasi ini, penulis berharap agar STITNU Al Mahsuni lebih siap untuk melakukan pencegahan kelulusan tidak tepat waktu pada mahasiswa.

\subsection{Rumusan Masalah}

1. Bagaimana cara mendapatkan data mahasiswa yang tidak lulus tepat waktu sebelum semester 6 ?

2. Bagaimana cara untuk meberikan Informasi mahasiswa yang memilki potensi tidak lulus tepat waktu Kepada dosen wali atau pihak akademik dengan lebih cepat dan mudah?

\subsection{Batasan Masalah}

1. Penelitian ini di lakukan di Sekolah Tinggi Ilmu Tarbiyah Nahdlatul Ulama (STITNU) Al Mahsuni Lombok Timur.

2. Penelitian ini menggunakan data mahasiswa sebagai tolak ukur perhitungan prediksi.

3. Peneliti menggunakan Algoritma KNN untuk melakukan pengolahan data prediksi.

4. Penelitian hanya dibatasi pada program studi PIAUD.

5. Aplikasi yang di buat peneliti berbasis Web. 


\subsection{Tujuan}

1. Mendapatkan data mahasiswa yang tidak lulus tepat waktu sebelum semester 6 .

2. Menyajikan informasi mahasiswa yang memiliki potensi lulus tidak tepat waktu lebih dini.

\section{TINJAUAN PUSTAKA}

\subsection{Tinjauan Pustaka}

Menurut (Prasetyo, et al., 2016) salah satu faktor yang menentukan kualitas sebuah perguruan tinggi adalah kemampuan lembaga pendidikan untuk mengarahkan dan membimbing mahasiswa untuk lulus tepat waktu. Sehingga prediksi kelulusan mahasiswa tepat waktu sangat di butuhkan setiap lembaga pendidikan yang sedang mencoba untuk menaikkan kualitas pendidikan. Penelitian yang dilakukan prasetyo menggunakan algoritma back proporgation neural network dan k-nearest neighbor untuk melakukan prediksi.

Dalam penelitiannya (Rohman, 2015) melakukan penelitian yang berjudul "MODEL ALGORITMA K-NEAREST NEIGHBOR (KNN) UNTUK PREDIKSI KELULUSAN MAHASISWA", Rohman menyatakan bahwa tingkat kelulusan mahasiswa tepat pada waktunya perlu di perhatikan. Rohman juga menambahkan bahwa prosentase naik turunnya kemampuan mahasiswa untuk menyelesaikan studi tepat waktu merupakan salah satu elemen penilaian akreditasi Universitas. Sehingga hal tersebut melatar belakangi penelitian untuk mencari nilai $\mathrm{K}$ yang paling optimal untuk memprediksi kelulusan mahasiswa dengan menggunakan usia, jenis kelamin, indeks prestasi semester satu sampai dengan indeks prestasi semester empat sebagai parameter perhitungan prediksi dalam penelitiannya..

\subsection{Landasan Teori}

\subsubsection{Prediksi}

Prediksi adalah suatu proses meramalkan atau memperkirakan secara sistematis tentang sesuatu yang akan terjadi di masa depan berdasarkan data yang di miliki sekarang. Prediksi tidak harus mencapai kesimpulan yang benar(sesuatu yang pasti terjadi), melainkan berusaha mencari kesimpulan atau hasil yang mendekati hasil sebenarnya (Aina, 2018).

\subsubsection{Kelulusan Tepat Waktu}

Setiap mahasiswa yang menempuh perkuliahan memiliki tenggat waktu yang sudah di tentukan oleh Direktorat Jendral Pendidikan Tinggi (DIRJEN DIKTI) sesuai dengan tingkat pendidikannya. Tenggat waktu yang di tentukan oleh DIRJEN DIKTI tersebut adalah lulus tepat waktu, melewati batas dan tidak lulus tepat waktu. menempuh masa pendidikan. Tepat waktu adalah waktu ideal menyelesaikan pendidikan tinggi. Sedangkan melewati batas adalah waktu paling lama yang diizinkan dikti untuk menempuh pendidikan tinggi, artinya jika mahasiswa sudah melewati batas waktu tertentu dan tidak menyelesaikan pendidikannya maka mahasiswa tersebut akan dinyatakan Drop Out (DO). Adapun tidak lulus tepat waktu adalah waktu atau masa seorang mahasiswa mampu menyelesaikan pendidikannya di antara waktu normal dan batas akhir.

\subsubsection{K-Nearest Neighbor (KNN)}

Algoritma K-Nearest Neighbor adalah metode yang menggunakan klasifikasi ketetanggaan (neighbor) sebagai nilai prediksi dari query instance yang baru (Banjarsari, et al., 2015). Susanto dalam tulisannya (Susanto, et al., 2018) menerangkan bahwa Klasifikasi ketetanggaan dalam metode KNN adalah klasifikasi yang di dasari oleh jarak data baru dengan tingkat kemiripan data baru tersebut terhadap data pola.

Adapun langkah-langkah untuk menghitung Metode k-Nearest Neighbor menurut (Banjar et al., 2015: 58) adalah sebagai berikut:

1.Menentukan parameter $\mathrm{k}$.

2.Menghitung jarak antara yang akan dievaluasi dengan semua pelatihan.

3.Mengurutkan jarak yang terbentuk.

4.Menentukan jarak terdekat sampai urutan $\mathrm{k}$.

5.Memasangkan kelas yang bersesuaian.

6.Mencari jumlah kelas dari tetangga yang terdekat dan tetapkan kelas tersebut sebagai kelas data yang akan dievaluasi.

Perhitungan jarak antara data baru dengan data lama dilakukan menggunakan rumus sebagai berikut.

$$
d=\sqrt{\sum_{i=1}^{p}\left(x_{2 i}-x_{1 i}\right)^{2}}
$$

Keterangan:

$\mathrm{x} 1=$ Sampel data

$\mathrm{x} 2=$ Data uji atau data testing

$\mathrm{i}=$ variabel data

$\mathrm{d}=$ jarak

$\mathrm{p}=$ Dimensi data

\subsubsection{WEB Aplication}

Web adalah sekumpulan halamen web yang saling terhubung dalam jaringan yang sama dan dapat di akses oleh user menggunakan aplikasi web browser. Web umumnya di sediakan oleh perorangan, kelompok, atau organisasi. Untuk mengakses sebuah web, setidaknya di butuhkan sebuah server untuk dapat di akses. Selain server, penyedia halaman web juga membutuhkan jaringan yang terhubung dengan target pengguna untuk dapat di akses.

\subsubsection{PHP}

PHP adalah singakan dari "Hypertext Preprocessor". yaitu bahasa pemrograman script 
server-side yang di disain untuk pengembangan web (Alan, 2018). Php di sebut pemrograman server-side karena perintah pada PHP hanya akan di eksekusi oleh processor server. Artinya sisi client hanya akan menerima output dari hasil proses script PHP pada server.

\subsubsection{CodeIgniter}

CodeIgniter adalah framework aplikasi berbasis web yang mengusung model MVC (Model, View, Controller). CodeIgniter sendiri di rilis pertama kali pada 28 Februari 2006 oleh EllisLab. Salah satu framework PHP ini dapat menjadi tools bagi seorang web developer untuk mengembangkan suatu situs dengan lebih mudah. Framework CodeIgniter memungkinkan pengembang untuk menuliskan sedikit kode dalam pembuatan web application karena sudah di rancang sedimikian rupa sehingga perintah yang panjang dan rumit bisa ditulis dengan kode yang lebih pendek dan sederhana. CodeIgniter sendiri merupakan Framework yang bersifat Open Source sehingga Framework, tutorial dan forumforum diskusi dapat di temukan dengan mudah di internet (Muharam, 2018).

\subsubsection{Akurasi}

Pengujian akurasi adalah pengujian yang memberikan informasi berupa nilai keakuratan hasil prediksi sistem jika dibandingkan dengan data real (Rahman, Hidayat, \& Supianto, 2018). Akurasi dapat diperoleh dengan membandingkan antara jumlah hasil yang benar dengan keseluruhan data. Akurasi dinyatakan dengan rumus

$$
\text { akurasi }=\frac{\text { total data benar }}{\text { total data }} \times 100 \%
$$

Keterangan :

Akurasi $=$ nilai akurasi hasil prediksi.

total data benar $=$ jumlah data hasil prediksi yang bernilai benar.

total data $=$ total data training.

Data hasil yang memiliki nilai sama dengan data sebenarnya (testing) di jumlahkan dan menjadi variabel total data benar. Variabel total data benar kemudian di bagi dengan jumlah total data testing, kemudian dikalikan dengan 100. Hasil tersebut adalah nilai akurasi prediksi yang di dapatkan.

\section{ANALISIS DAN PERANCANGAN}

\subsection{Analisa Kebutuhan}

\subsubsection{Analisis Kebutuhan Perangkat Keras}

Dalam pembuatan Aplikasi Prediksi Kelulusan Mahasiswa Tepat Waktu di Sekolah Tinggi Ilmu Tarbiyah Nahdlatul Ulama (STITNU) Al Mahsuni Lombok Timur, perangkat keras yang dibutuhkan adalah laptop dengan spesifikasi sebagai berikut:
a. Intel(R) Celeron(R) CPU 1019Y @ 1.00GHz
b. 2.00 GB RAM
c. Intel(R) HD Graphics

\subsubsection{Analisis Kebutuhan Perngkat Lunak}

Selain perangkat keras, perangkat lunak juga di butuhkan untuk membangun aplikasi ini. Adapun perangkat lunak yang di butuhkan adalah sebagai berikut:

\section{Sistem Operasi Windows 7 Ultimate 64-bit}

Windows 7 adalah salah satu jenis system operasi yang banyak di gunkanan di Indonesia. Selain karena banyak pengguna sehingga mudah untuk belajar, kemudahan dalam berbagi data juga merupakan pertimbangan yang sangat menentukan ketika memilih system operasi ini sebagai system operasi utama dalam bekerja maupun belajar di Indonesia.

\section{Visual Studio Code}

Visual Studio Code merupakan texteditor yang sudah di perkaya dengan banyak pilihan tool yang dapat memudahkan pengembang website untuk melakukan tugasnya. Visual Studio Code sendiri di terbitkan oleh Microsoft. Visual Studio Code di lengkapi dengan Sugestion dan Hot-Key untuk memudahkan pengembang dalam menulis kode.Visual Studio Code bahkan membebaskan pengguna untuk merubah dan memodifikasi Hot-Key untuk kenyamanan pengguna agar lebih mudah dan cepat ketika menulis kode. Selain fungsinya, Visual Studio Code juga memungkinkan pengguna atau pengembang untuk mengubah tema tampilannya.

\section{XAMPP}

XAMPP adalah sebuah tool yang menyediakan seperangkat software yang berfungsi untuk membangun server yang berdiri sendiri (localhost). Dengan menginstall XAMPP, maka tidak perlu lagi memasang Apache, PHP dan MySQL karena XAMPP sudah menyediakan hal tersebut secara otomatis $(3,2020)$.

\subsubsection{Analisis Pengujian Fungsional}

\section{Mozilla FireFox}

Mozilla FireFox adalah aplikasi browser yang di publikasikan oleh Mozilla, tersedia dalam berbagai jenis platform dengan kompabilitas yang kuat (contributors, 2019). Mozilla FireFox merupakan sebuah browser yang mudah di gunakan dan baik dalam performanya.

\section{Google Chrome}

Google Chrome adalah sebauh aplikasi browser yang di publikasikan oleh Google.Inc. Browser ini adalah aplikasi yang bersifat open source, artinya siapa saja dapat menjadi pengembang aplikasi ini. Proyek pengembangan aplikasi ini yang disebut proyek chromium oleh pihak goole, merupakan sebuah proyek yang menggunakan mesin rendering webkit sampai dengan versi 27 dan dirancang untuk bekrja dengan kecepatan diatas rata-rata namun tetap ringan di jalankan di perangkat dekstop dan mobile. 
3. Microsoft edge

Microsoft edge adalah browser bawaan dari windows 10 . Sebelumnya, browser ini di beri nama internet explorer. Namun setelah melakukan upgrade terus menerus, pihak microsoft merilis microsoft edge sebagai pengganti internet explorer. Microsoft Edge dirancang untuk pengguna masa kini yang mengutamakan performa.

\subsection{Perancangan}

\subsubsection{Struktur Menu}

Menurut penelitian yang dilakukan, adapun struktur menu yang dibutuhkan sebagai berikut:

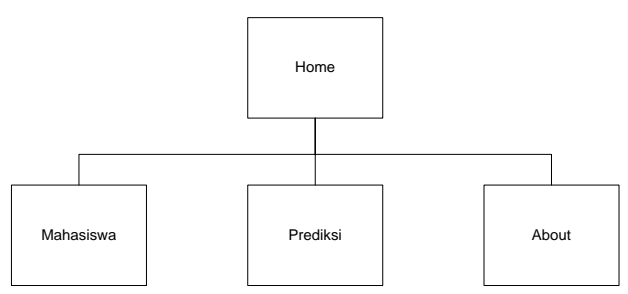

Gambar 3.1 Struktur Menu

\section{Home}

Menu home adalah menu pertama yang di tampilkan ketika aplikasi pertama kali di akses. Menu home berisi ucapan selamat datang untuk pengguna. Adapun navigation bar yang berisi nama-nama menu yang bisa di akses juga di tampilkan di bagian atas frame aplikasi, fungsinya adalah ketika nama menu terpilih maka akan langsung di alihkan ke menu tersebut.

\section{Prediksi kelulusan}

Prediksi Kelulusan adalah sebuah menu yang berisi baris record hasil prediksi dalam sebuah tabel. Adapun tabel-tabel tersebut bisa diexport menjadi file excel, pdf, CSV, Print, dan salin ke clipboard.

\section{Mahasiswa}

Data Mahasiswa adalah sebuah menu yang menampilkan data Mahasiswa dalam database. Pada menu ini juga di sertakan menu untuk menambahkan data dan fitur export sebagai pelengkap.

\section{About}

About adalah sebuah menu yang isinya adalah informasi seputar pengembangan aplikasi.

\subsubsection{Flowchart}

1. Flowchart Sistem

Flowchart aplikasi secara umum dapat di lihat seperti di bawah ini.

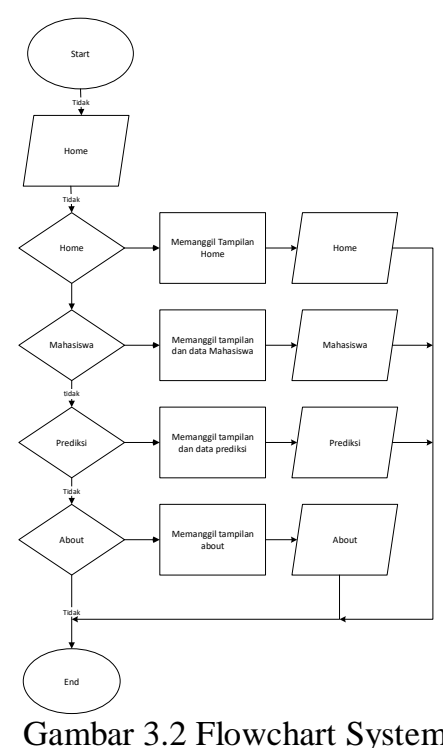

Ketika awal mula mengakses website ini, pengguna akan langsung di arahkan ke menum Home secara default. Pada menu ini akan di tampilkan ucapan selamat datang sebagai bentuk konfirmasi bahwa pengguna sudah bisa mengakses website ini. Adapun pada bagian atas atau tepatnya navigation bar di sediakan pilihan menu yang bisa di akses oleh pengguna antara lain:

a. Home

Apabila pengguna memilih menu Home, maka pengguna akan di alihkan ke halaman menu Home atau halaman awal ketika website pertama kali di akses. jika pengguna saat ini sedang di menu Home, maka pengguna akan mengakses ulang Home atau secara tidak lengsung pengguna melakukan perintah Refresh pada halaman web.

b. Mahasiswa

Apabila pengguna memilih menu Mahasiswa, maka pengguna akan dialihkan ke halaman menu Mahasiswa daftar data diri Mahasiswa. Jika pengguna sedang di halaman ini, maka secara tidak langsung pengguna sedang melakukan Refresh pada halaman Mahasiswa.

\section{c. Prediksi Kelulusan}

Apabila pengguna memilih menu prediksi, maka pengguna akan dialihkan ke halaman menu Prediksi Kelulusan yang berisi daftar hasil prediksi kelulusan mahasiswa. Jika pengguna sedang di halaman Prediksi Kelulusan, maka secara tidak langsung pengguna sedang melakukan Refresh pada halaman Prediksi Kelulusan.

d. About

Apabila pengguna memilih menu Tentang, maka pengguna akan dialihkan ke halaman tentang 
yang berisi informasi seputar pengembangan aplikasi ini. Jika pengguna sedang di halaman Tentang, maka pengguna secara tidak langsung sedang melakukan Refresh pada halaman Tentang.

\subsubsection{Diagram Alir Data (Data Flow Diagram)}

1. DFD Level 0

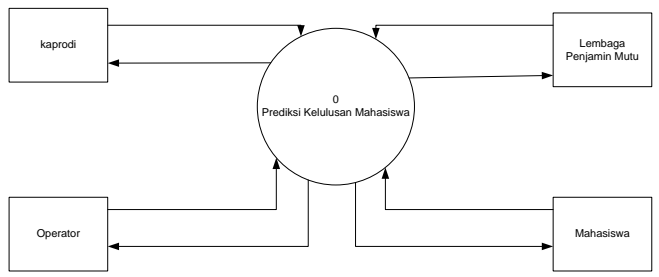

Gambar 3.4 DFD Level 0

2. DFD Level 1

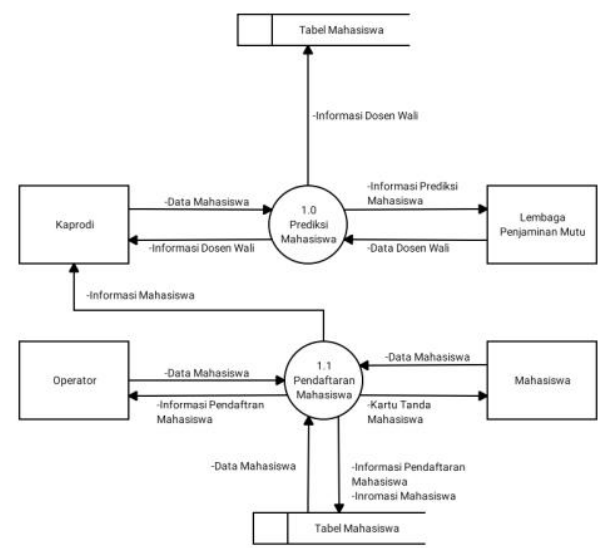

Gambar 3.5 DFD Level 1

\subsubsection{Perancangan Tabel}

Pada penelitian ini penulis merancang sebuah rancangan tabel berdasarkan format tabel yang didapatkan dari pengumpulan data. Adapun NIRM, NIRL, Nomor Ijazah dan sejenisnya tidak di tampilkan atau di buat fieldnya dengan alasan menjamin keamanan data pribadi mahasiswa.

Tabel Mahasiswa

\begin{tabular}{|c|c|c|c|c|c|}
\hline No & Keterangan & Nama Field & $\begin{array}{c}\text { Type } \\
\text { Data }\end{array}$ & $\begin{array}{c}\text { Maximum } \\
\text { Value }\end{array}$ & $\begin{array}{c}\text { Primary } \\
\text { Key }\end{array}$ \\
\hline 1 & Nim & id & Integer & - & Yes \\
\hline 2 & Nama & nama & Varchar & 50 & - \\
\hline & $\begin{array}{c}\text { Memiliki } \\
\text { pekerjaan }\end{array}$ & sk & Text & - & - \\
\hline 4 & Status Nikah & sn & Varchar & 1 & - \\
\hline 5 & Jenis Kelamin & jk & Varchar & 30 & - \\
\hline 6 & Tempat Lahir & tempatlahir & varchar & 50 & - \\
\hline 7 & Tanggal Lahir & tanggallahir & Varchar & 1 & - \\
\hline 8 & Alamat & alamat & Varchar & 1 & - \\
\hline 9 & Tahun Masuk & thmasuk & Varchar & 1 & - \\
\hline 10 & Tahun Lulus & thlulus & Int & - & - \\
\hline 11 & Label & label & int & - & - \\
\hline 12 & Jurusan SMA & Jurusansma & Int & - & - \\
\hline 13 & Pekerjaan Ortu & Portu & Portu & - & - \\
\hline \multicolumn{7}{r}{} & & &
\end{tabular}

Tabel Testing

\begin{tabular}{|c|c|c|c|c|c|}
\hline No & Keterangan & Nama Field & $\begin{array}{c}\text { Type } \\
\text { Data }\end{array}$ & $\begin{array}{c}\text { Maximum } \\
\text { Value }\end{array}$ & $\begin{array}{c}\text { Primary } \\
\text { Key }\end{array}$ \\
\hline 1 & Nim & id & Integer & - & Yes \\
\hline 2 & Nama & nama & Varchar & 50 & - \\
\hline 3 & $\begin{array}{c}\text { Memiliki } \\
\text { pekerjaan }\end{array}$ & sk & Text & - & - \\
\hline 4 & Status Nikah & sn & Varchar & 1 & - \\
\hline 5 & Jenis Kelamin & jk & Varchar & 30 & - \\
\hline 6 & Tempat Lahir & tempatlahir & varchar & 50 & - \\
\hline 7 & Tanggal Lahir & Tanggallahir & Varchar & 1 & - \\
\hline 8 & Alamat & Alamat & Varchar & 1 & - \\
\hline 9 & Tahun Masuk & Thmasuk & Varchar & 1 & - \\
\hline 10 & Tahun Lulus & Thlulus & Int & - & - \\
\hline 11 & Jurusan SMA & Jurusansma & Int & - & - \\
\hline
\end{tabular}

Tabel MK

\begin{tabular}{|c|c|c|c|c|c|}
\hline No & Keterangan & $\begin{array}{c}\text { Nama } \\
\text { Field }\end{array}$ & Type Data & $\begin{array}{c}\text { Maximum } \\
\text { Value }\end{array}$ & $\begin{array}{c}\text { Primary } \\
\text { Key }\end{array}$ \\
\hline 1 & Id jurusan & Jurusansma & int & - & Yes \\
\hline 2 & Nama Jurusan & Mk & Varchar(30) & - & - \\
\hline
\end{tabular}

\section{3. k-NN}

Algoritma k-NN merupakan sebuah algoritma yang di pilih peneliti untuk mencari hasil prediksi pada penelitian ini. Algoritma ini sendiri di eksekusi di oleh server menggunakan bahasa pemrograman PHP. Beikut adalah langkah-langkah untuk mencari hasil prediksi pada penelitian ini:

1. Memilah Data

Pada proses ini peneliti memilah data induk(seluruh data) menjadi data training dan dat testing. Dalam pemilahan data ini, peneliti mengunakan rasio 75:25 yaitu $75 \%$ untuk data training dan $25 \%$ untuk data testing (Wahyono, 2020). Dari total 185 data di dapati 139 data sebagai data training dan 45 data sebagai data testing.

\section{Konversi data}

Konversi data adalah sebuah proses mengubah record yang bernilai linguistik menjadi nilai nominal. Adapun kolom yang di konversi dan perubahannya adalah sebagai berikut:

Tabel 3.4. Tabel konversi Linguistik

\begin{tabular}{|c|c|c|}
\hline Label & Linguistik & Hasil Konversi \\
\hline Memiliki tanggungan & $\mathrm{Y} / \mathrm{T}$ & $1 / 2$ \\
\hline Status nikah & $\mathrm{Y} / \mathrm{T}$ & $1 / 2$ \\
\hline Jk & Pria/Wanita & $1 / 2$ \\
\hline
\end{tabular}

Keterangan :

Label $=$ nama field dalam database

Linguistik = nilai sebenarnya

Hasil konversi $=$ hasil perubahan nilai linguistik menjadi nilai nominal.

Tabel di atas menunjukkan perubahan sebuah nilai linguistik menjadi nilai nominal (hasil Konversi). Pada tabel di atas, dapat dilihat bahwa setiap nilai linguistk $Y$ dan Pria diubah menjadi nominal 1 dan setiap nilai linguistik $\mathrm{T}$ dan Wanita diubah menjadi nilai nominal 2. 
Tabel 3.5. Konversi jurusan

\begin{tabular}{|c|c|}
\hline JURUSAN & ID \\
\hline AGAMA & 1 \\
\hline BAHASA & 2 \\
\hline BUDAYA & 3 \\
\hline ILMU-ILMU BIOLOGI & 4 \\
\hline IPA & 5 \\
\hline IPS & 6 \\
\hline KEAGAMAAN & 7 \\
\hline MA & 8 \\
\hline MULTIMEDIA & 9 \\
\hline PAKET C & 10 \\
\hline SMA & 11 \\
\hline SMK & 12 \\
\hline SPG & 13 \\
\hline
\end{tabular}

Keterangan :

Jurusan = Nama Jurusan yang tersimpan dalam database

ID = nomor record sekaligus menjadi hasil konversi linguistik.

Dari tabel konversi jurusan di atas, dapat dilihat bahwa konversi jurusan didasarkan pada nomor record jurusan tersebut di dalam database. Nomor record di dapatkan dari properties ID/nomor record yang sudah di atur menjadi auto increment.

\section{Menghitung jarak}

Proses ini adalah proses menghitung jarak antara data yang akan di prediksi(data testing) dengan semua data training. Pada proses ini di hitung jarak antara 1 data testing dengan 139 data training menggunakan rumus eucledian.

4. Jika masih ada data testing yang lain, maka ganti data testing di atas dengan data testing selanjutnya dan ulangi langkah 3 dan 4 sampai seluruh data testing mendapatkan hasil prediksi. Adapun hasil prediksi dapat dilihat pada tabel berikut ini :

Tabel 3.11. Hasil Prediksi

\begin{tabular}{|c|c|c|c|c|c|c|c|c|c|c|}
\hline \multirow{2}{*}{ Nim } & \multicolumn{10}{|c|}{ Hasil prediksi } \\
\cline { 2 - 11 } & K 1 & K 2 & K 3 & K 4 & K 5 & K 6 & K 7 & K 8 & K 9 & K 10 \\
\hline 01.16 .003 & Telat & Telat & Telat & Telat & Telat & Telat & Telat & Telat & Telat & Telat \\
\hline 01.16 .004 & Telat & Telat & Telat & Telat & Telat & Telat & Telat & Telat & Telat & Telat \\
\hline 01.16 .005 & Telat & Telat & Telat & Telat & Telat & Telat & Telat & Telat & Telat & Telat \\
\hline 01.12 .021 & Telat & Telat & Telat & Telat & Telat & Telat & Telat & Telat & Telat & Telat \\
\hline 01.12 .022 & Telat & Telat & Telat & Telat & Telat & Telat & Telat & Telat & Telat & Telat \\
\hline 01.12 .024 & Telat & Telat & Telat & Telat & Telat & Telat & Telat & Telat & Telat & Telat \\
\hline 01.12 .025 & Telat & Telat & Telat & Telat & Telat & Telat & Telat & Telat & Telat & Telat \\
\hline.. &.. &.. &.. &.. &.. &.. &.. &.. &.. &.. \\
\hline.. &.. &.. &.. &.. &.. &.. &.. &.. &.. &.. \\
\hline 01.13 .014 & Telat & Telat & Telat & Telat & Telat & Telat & Telat & Telat & Telat & Telat \\
\hline
\end{tabular}

Keterangan :

$\mathrm{NIM}=$ nomor induk mahasiswa data testing

Hasil Prediksi $=$ hasil prediksi berdasarkan nilai $\mathrm{k}$

$\mathrm{K}=$ hasil prediksi berdasarkan jumlah tetangga terdekat dari data testing terhadap data training

Kolom k merupakan kolom hasil prediksi berdasarkan nilai $\mathrm{k}$. contohnya kolom $\mathrm{k} 1$ adalah hasil prediksi apabila $\mathrm{k}$ bernilai 1 . Begitupun kolom $\mathrm{k} 2$ adalah hasil prediksi apabila $\mathrm{k}$ bernilai 2 dan seterusnya.

\section{IMPLEMENTASI DAN PENGUJIAN}

\subsection{Implementasi}

Tahap implementasi merupakan tahap penerapan hasil perancangan sistem yang telah di susun menjadi sebuah aplikasi dan siap untuk di jalankan. Implementasi pengembangan prediksi kelulusan mahasiswa menggunakan metode $k$-Nearest Neighbor, sehingga dapat menjadi bahan pertimbangan pihak STITNU Al Mahsuni dalam pengembangannya lebih lanjut.

\subsubsection{Menu Home}

Menu Home adalah halaman atau menu yang pertama kali di tampilkan ketika program pertama kali di jalankan. Pada menu ini akan di muncul ucapan selamat datang kepada pengguna. Berikut adalah tampilan Menu Home yang di tunjukkan pada gambar 4.1

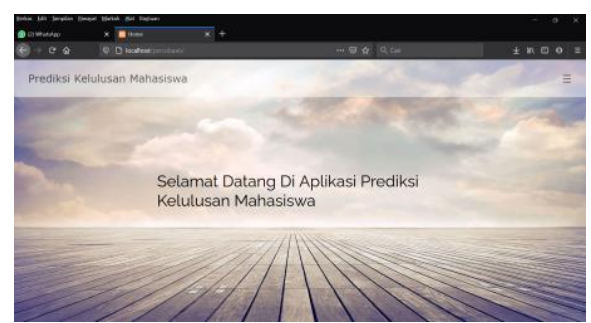

Gambar 4.1. Menu Home

\subsubsection{Menu Mahasiswa}

Menu Mahasiswa adalah menu yang menampilkan data pribadi mahasiswa yang sudah lulus dalam sebuah tabel. Data yang di tampilkan pada menu ini akan di gunakan sebagai data training dalam proses prediksi nantinya. Tampilan pada menu ini dapat di lihat pada gambar 4.2

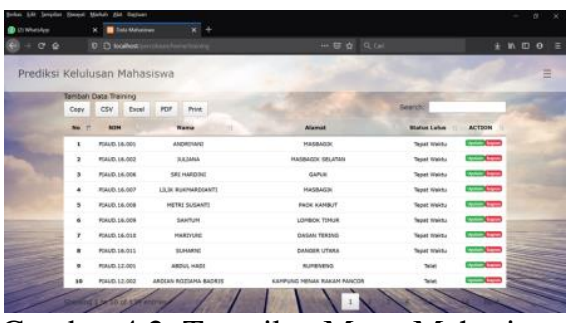

Gambar 4.2. Tampilan Menu Mahasiswa

\subsubsection{Menu Prediksi}

Menu Prediksi adalah menu yang menampilkan data mahasiswa yang belum lulus beserta hasil prediksinya. Tampilan Menu Prediksi dapat di lihat pada gambar 4.8

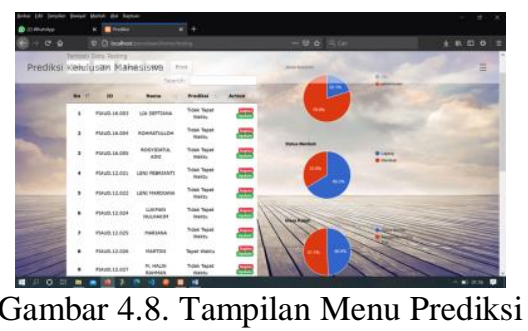


Adapun fitur-fitur yang di tawarkan pada menu ini adalah sama dengan fitur-fitur yang ada pada Menu Mahasiswa.

\subsubsection{Menu About}

Menu About adalah menu yang berisi keterangan seputar aplikasi dan pengembang. Tampilan Menu About di tunjukkan pada gambar 4.9

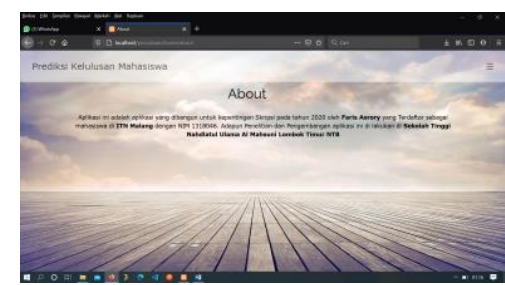

Gambar 4.9. Tampilan Menu About

\subsection{Pengujian}

Pengujian merupakan tahap uji coba dari sistem untuk menguji setiap fungsi agar nantinya dapat diambil kesimpulan apakah sistem berjalan dengan baik atau tidak.

\subsubsection{Pengujian Fungsional}

Pengujian fungsional merupakan proses menampilkan sistem pada beberapa browser yang berbeda. Pengujian ini bertujuan untuk menemukan kesalahan yang mungkin terjadi sebelum aplikasi di publikasikan.

Tabel 4.1. Pengujian Fungsional

\begin{tabular}{|l|l|l|l|}
\hline \multirow{2}{*}{ Fungsi } & \multicolumn{3}{|c|}{ Browser } \\
\cline { 2 - 5 } & MF & GC & ME \\
\hline Tambah data testing & $\sqrt{ }$ & $\sqrt{ }$ & $\sqrt{ }$ \\
\hline Tambah data training & $\sqrt{ }$ & $\sqrt{ }$ & $\sqrt{ }$ \\
\hline Prediksi & $\sqrt{ }$ & $\sqrt{ }$ & $\sqrt{ }$ \\
\hline Update, Delete testing & $\sqrt{ }$ & $\sqrt{ }$ & $\sqrt{ }$ \\
\hline Update, Delete training & $\sqrt{ }$ & $\sqrt{ }$ & $\sqrt{ }$ \\
\hline COPY,CSV,EXCEL,PDF,PRINT & $\sqrt{ }$ & $\sqrt{ }$ & $\sqrt{ }$ \\
\hline
\end{tabular}

\subsubsection{Pengujian k-NN}

Pengujian ini di lakukan untuk mengetahui persentase keakuratan sistem dengan membandingkan label data testing dengan label hasil prediksi. Dalam penelitian ini peneliti menggunakan 189 data yang sudah di normalisasi. Dimana 139 diantaranya di pilah menjadi data training dan 45 lainnya di pilah untuk menjadi data testing.

Setelah melakukan persiapan, peneliti kemudian menerapkan perhitungan pada sistem. Selanjutnya peneliti melakukan uji akurasi untuk melihat nilai akurasi prediksi jika dibandingkan dengan data sebenarnya. Adapun hasil pengujian akurasi dapat dilihat pada tabel berikut ini.
Tabel 4.5. Tabel Akurasi

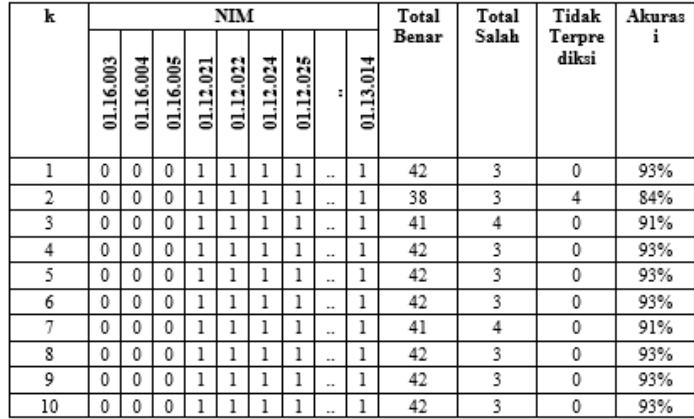

Keterangan:

$\mathrm{K}$ = jumlah tetangga dengan jarak terdekat

Total benar = jumlah label yang sesuai antara data asli dengan data hasil prediksi

Total salah = jumlah label yang tidak sesuai antara data asli dengan data hasil prediksi

Tidak terprediksi = jumlah data yang tidak dapat di prediksi

Akurasi = nilai akurasi

NIM = nilai kesesuaian hasil prediksi berdasarkan nim

Berdasarkan data diatas, di dapati nilai akurasi tertinggi adalah prediksi dengan menggunakan $\mathrm{k}$ 1,4,5,6,8,9 dan 10 yang masing-masing memiliki nilai akurasi 93,33\%. Selanjutnya nilai akurasi tertinggi ke 2 adalah prediksi dengan nilai $\mathrm{k} 3$ dan 7 yang masingmasing memiliki nilaii akurasi $91,11 \%$. Sedangkan prediksi dengan nilai $\mathrm{k} 2$ memilki nilai akurasi $84,44 \%$, yang juga sekaligus dapat di kategorikan sebagai nilai akurasi paling rendah dalam pengujian di atas.

Nilai k 2 memiliki nilai akurasi paling rendah karena dalam prediksinya terdapat hasil yang tidak diinginkan. Hasil yang tidak diinginkan adalah prediksi yang tidak dapat menentukan hasil klasifikasi. Dalam kasus ini, hal ini terjadi karena dari 2 tetangga terdekat yang di tentukan masing-masing memiliki 1 klasifikasi Tepat Waktu dan 1 klasifikasi Telat. Dengan 2 klasifikasi yang memiliki jumlah yang sama (tidak ada klasifikasi dominan), sitem tidak dapat menentukan klasifikasi datatesting atau hasil prediksi sehingga di sebut sebagai klasifikasi Tidak Terprediksi.

\section{Penutup}

\subsection{Kesimpulan}

Berdasarkan permasalahan dan hasil pengujian yang telah di lakukan maka dapat di ambil kesimpulan antara lain:

1. Prediksi menggunakan metode k-NN dengan parameter jenis kelamin, memiliki pekerjaan/membiayai kuliah secara mandiri, status pernikahan, umur dan jurusan SMA pada mahasiswa STINU Al Mahsuni Lombok Timur dapat dilakukan.

2. Pada proses pengujian nilai $\mathrm{k}$ penguji mendapatkan $\mathrm{k}$ dengan nilai 1,4,5,6,8,9 dan 10 
memiliki nilai akurasi tertinggi yaitu dengan nilai akurasi 93,33\%. Selanjutnya untuk nilai k dengan nilai akurasi tertinggi ke-2 adalah k-3 dan k-7 dengan nilai akurasi 91,11\%. Adapun k2 menjadi nilai $\mathrm{k}$ dengan akurasi terendah dengan nilai akurasi 84,44.

\subsection{Saran}

Berdasarkan penelitian yang dilakukan penulis, terdapat bebrapa saran untuk di jadikan bahan pertimbangan oleh peneliti selanjutnya yaitu sebagai berikut :

1. Algoritma k-nearest neighbor merupakan metode yang menggunakan kedekatan nilai dari tetangga terdekat $(\mathrm{k})$ sebagai tolak ukur hasil perhitungan. Untuk menghindari klasifikasi Tidak Terprediksi muncul dalam hasil prediksi, alangkah baiknya menghindari penggunaan $\mathrm{k}$ dengan nilai yang sama dengan jumlah label yang sudah di tentukan. Dalam kasus penelitian ini adalah nilai $\mathrm{k}$ dengan jumlah label adalah sama-sama 2 sehingga ada kemungkinan untuk setiap tetangga mewakili label yang berbeda dan pada akhirnya tidak dapat menentukan label dominan dari tetangga terdekat.

2. Algoritma k-nearest neighbor merupakan salah satu metode yang digunakan untuk melakukan prediksi, salah satu contohnya adalah penelitian ini. Untuk mendapatkan hasil prediksi yang lebih optimal dalam sebuah kasus, dapat di lakukan perbandingan antara algoritma ini dengan algoritma prediksi lain sejenis.

\section{DAFTAR PUSTAKA}

[1]. 3, D. P., 2020. XAMPP adalah. [Online] Available at: https://www.dosenpendidikan.co.id [Accessed 27 Mei 2020].

[2]. Alan, 2018. Pengertian dan Fungsi Pemrograman PHP. [Online] Available at: https://alan.co.id [Accessed 21 Maret 2020].

[3]. Banjarsari, M. A., Budiman, H. I. \& Farmadi, A., 2015. Penerapan K-Optimal Pada Algoritma Knn untuk Prediksi Kelulusan Tepat Waktu Mahasiswa Program Studi Ilmu Komputer Fmipa Unlam Berdasarkan IP Sampai Dengan Semester
4. Kumpulan jurnaL Ilmu Komputer (KLIK), Volume 02, p. 58.

[4]. contributors, M., 2019. Firefox. [Online] Available at: https://developer.mozilla.org [Accessed 27 Mei 2020].

[5]. Hatmoko, A., 2019. Pengertian Aplikasi Berbasis WEB. [Online] Available at: https://www.kompasiana.com [Accessed 21 Maret 2020].

[6]. Muharam, A., 2018. Apa Itu CodeIgniter dan Keunggulannya. [Online] Available at: https://www.logique.co.id [Accessed 27 mei 2020].

[7]. Pangkalan Data Pendidikan Tinggi (PDDikti), 2018. Statistik Perguruan Tinggi. [Online] Available at: https://pddikti.kemdikbud.go.id [Accessed 21 Maret 2020].

[8]. Prasetyo, T. F., Susandi, D. \& Widianingrum, I. S., 2016. PREDIKSI KELULUSAN MAHASISWA PADA PERGURUAN TINGGI KABUPATEN MAJALENGKA BERBASIS KNOWLEDGE BASE SYSTEM. Bandung, s.n.

[9]. Rohman, A., 2015. MODEL ALGORIMA KNEAREST NEIGHBOR (K-NN) UNTUK PREDIKSI KELULUSAN MAHASISWA. JURNAL ILMIAH TEKNOLOGI.

[10]. Setiawan, P., 2020. Sistem Operasi Sejarah, Tujuan, Jenis, Evolusi, Macam, Komponen. [Online] Available at: https://www.gurupendidikan.co.id [Accessed 27 mei 2020].

[11]. Susanto, E. S., Kusrini \& Fatta, H. A., 2018. PREDIKSI KELULUSAN MAHASISWA MAGISTER TEKNIK INFORMATIKA UNIVERSITAS AMIKOM YOGYAKARTA MENGGUNAKAN METODE K-NEAREST NEIGHBOR. Jurnal Teknologi Informasi, Volume XIII, p. 68.

[12]. UNDANG-UNDANG REPUBLIK INDONESIA NOMOR 12 tahun 2012, 16 juli 2013. PENDIDIKAN TINGGI. [Online] Available at: http://sumberdaya.ristekdikti.go.id [Accessed 21 MARET 2020]. 